\title{
Need of recognition of traditional institution and use of indigenous knowledge in climate change adaptation: A case-study in Mustang district, Nepal
}

\author{
Sushant Acharya ${ }^{1 *}$, Ramu Subedi $^{2}$ and Hridaya Shrestha ${ }^{3}$ \\ ${ }^{1}$ South Asia Institute for Advanced Studies (SIAS), Kathmandu \\ ${ }_{3}^{2}$ Nepal Environment and Scientific Society, Kathmandu \\ ${ }^{3}$ District Soil Conservation Office, Mustang
}

\begin{abstract}
Contemporary researches have revealed that traditional institutions are very strong in governing natural resources. They possess rich pool of indigenous knowledge which is valuable to adapt extreme environmental conditions. On the other side, it is less studied about how indigenous knowledge can be used and how traditional institutions can be mobilized in planned climate change adaptation initiatives at local level. In the mean time, Mustang district has prepared climate adaptation plans for all communities and declared as the first district to have such plans. On this backdrop, this study has explored climate change, state of adaptation and role of traditional institutions impacts in Mustang. The findings of the study revealed that climate change in Mustang is at much faster pace than in other regions. Local people have practiced autonomous adaptation and used indigenous knowledge in diversifying livelihood opportunities. The traditional institution-Mukhiya and mother groups have played important role in adaptation process through good governance of critical natural resources- forest, land and water. They practiced equity in participation and benefit sharing. The planned adaptation process has initiated by formal institutions following a participatory approach. But, these adaptation plans have neither recognized the role of Mukhiya nor mentioned about the use of indigenous knowledge in adaption processes. This paper concludes that indigenous knowledge integrated with scientific knowledge; and mobilization of traditional institutions together with formal institutions can excel adaptive capacity development in efficient and more sustainable way. Thus, this paper urges for formal recognition of traditional institution and integration of indigenous knowledge in planned adaptation initiatives.
\end{abstract}

Key words: Climate change adaptation, Integration, Mukhiya, Scientific knowledge

\section{Introduction}

Nepal is known for its geographical, ecological, ethnic, cultural and linguistic diversity. The national census has recognized 126 indigenous caste and ethnic groups (CBS, 2011). According to the Indigenous Nationalities Act (2002) of Nepal, indigenous people are people having their own mother tongue, distinct traditional values, and cultural identities, including social str ucture and written/non-written history (as cited, Rimal, 2011). These people have rich knowledge tested from their adjustments in var ying climatic conditions and this is enriched, sustained and improved over time by succeeding generations (MoSTE, 2015). Indigenous knowledge system has close linkage with traditional governance institutions (Agrawal, 2008). Naess (2013) argues that traditional institutions can better facilitate responses to climate change and warns not to rely solely on scientific knowledge and tools. These institutions support in transferring such knowledge from generation to generation (UNFCC, 2013, as cited MoSTE, ${ }^{*}$ Corresponding author, email address: sushant11bg|@gmail.com
2015). Indigenous knowledge provides better options than extemal approaches in responding immediate climate risks (Nakashima et al., 2012).

Mustang, trans Himalayan district of Nepal, is not only a famous for landscape beauty, but also unique in culture. But, in recent years, Mustang is facing negative impacts of climate change which have perverse local eco-system and livelihoods of local people (Dahal, 2005). Some negative impacts of climate change include drying of village springs, reduction in production of grass, cereal crops, increased diseases in fr uits, more frequent flash floods, landslides, increase in frequency and severity of natural disasters. These impacts have pushed the basic livelihoods of local people at risk (DDC Mustang, 2016; Pradhan et al., 2012). Climate induced internal displacement has become common phenomena. The National Adaptation Programme of Action (NAPA) has put this district under climate vulnerable district category (MoSTE, 2010). 
The planned adaptation has begun in Mustang in the leadership of for mal institutions (gover nment and non-gover nment organizations). The climate vulnerability has been assessed for each settlement in the district and Local Adaptation Plan of Action (LAPA) has been prepared for all settlements located in sixteen Village Development Committees (VDCs). The District Development Committee has declared Mustang district as the first district among the seventy-five to have such plans. These LAPAs are formally endorsed from local government- the VDC and District Development Committee (DDC) and has mainstreamed in the Five-Year Periodic Plan of Mustang district (DDC Mustang, 2016). LAPA preparation approach was guided by the National Framework on LAPA (MoSTE, 2011), National Adaptation Programme of Action (NAPA) (MoSTE, 2010) and Climate Change Policy (GoN, 2011). The local government took lead in the preparation of LAPA as well as its implementation process. Though the bottom-up and consultative process was followed in developing adaptation, use of indigenous knowledge and potential role of traditional institution such as Mukbiya in the implementation of adaptation programme is not reflected in such plans.

Thakali (2012) argues that Mukbiya institution is dominant for overall local governance processes including the management of natural resources sector. The past researches in Mustang have also highlighted the role of Mukbiya as well-functioning infor mal organization that manages social, economic and judicial affairs of the local community. This social capital is well recognized as valuable resource in climate adaptation and disaster risk reduction initiatives at local level (Chaudhar y et al., 2017; MoSTE, 2015). But, the connecting link is missing. Traditional institutions and formal institutions have own way of planning and implementing climate adaptation measures. But, it is sure that combined use of scientific knowledge and indigenous knowledge in responding climate change generate synergic impacts (Mercer et al., 2010).

On this backdrop, this paper investigates the response to climate change impacts in Mustang district. This paper critically reviews the autonomous climate adaptation and role of traditional institution in the adaptation process. In addition, this paper also explores the planned adaptation process and role of for mal institution in adaptive capacity building of local people. This research has reviewed L APAs of Mustang district, however, indepth study was carried out in Muktinath VDC. The focused group discussions (FGD), k ey infor mants interview (KII) and field observation were primar y tools for data collection. Lik ewise, secondary information was gathered from field records, reports and accessed from digital sources. The findings of the research are then discussed with contemporary policies and practices to come to the conclusion.

\section{Indigenous knowledge}

Indigenous knowledge is defined as multi-faceted ar rays of knowledge, know-how, practices and representations that guide societies in their interactions with their natural surroundings. The interaction between people and place give rise to diversity in knowledge system which is empirical and symbolic, pragmatic and intellectual, and traditional and adaptive (Icsu, 2002; Berkes, 2012 as cited MoSTE, 2015). Indigenous knowledge system is dynamic and specific to culture (MoSTE, 2015). This knowledge provides an inherent connection to one's sur roundings and environment, including climate change (Woodley, 1991 as cited, Ajani et al., 2013). Indigenous people have capacity to adjust their behaviours to adapt the changes in climate (Tebtebba Foundation, 2013, as cited MoSTE, 2015). The indigenous technologies, they developed are now proved ecologically sustainable and adaptable in climate adaptation (IFAD, 2009).

\section{Traditional institution}

Traditional institutions are set of social $r$ ules and nor ms that stipulate what actions are required, permitted, or forbidden in a particular situation. Traditional institutions play key role in mediating the 'quality' and 'access' of natural and manmade systems and acknowledge for practice of 'good gover nance' (Pradhan et al., 2012). These institutions play central role in social networking and shaping people's responses to climate adaptation (MoSTE, 2015). They are strong and historically credible or ganizations capable to appropriate natural resources (Sherpa et al., 2013). The close link between indigenous knowledge and traditional institution is useful in climate adaptation (MoSTE, 2015).

\section{Climate adaptation}

Adaptation is an adjustment to behaviour or economic structures that reduce vulnerability of society in the face of scarcity or threatening environmental change (Adger et al., 2007; as cited Forsyth \& Evans, 2013). According to Intergovernmental Panel on Climate Change (IPCC, 2007) planned adaptation is a result of deliberate interventions. In planned adaptation information about present and future climate change is reviewed and adaptation measures are proposed according to their suitability to cur rent and planned practices, policies, and infrastructure (Fussel, 2007). The autonomous adaptation is not a conscious response to climate stimuli, but it is triggered by ecological changes in natural systems; and by market or welfare changes in human systems. Livelihood diversification is a form of adaptation in the case where people are less reliant on resources that are threatened by environmental changes (Sabates-Wheeler et al., 2008, as cited Forsyth \& Evans, 2013).

\section{Knowledge integration}

There is growing awareness on valuing and using indigenous knowledge together with scientific knowledge to combat environmental hazards and disasters (Mercer et al., 2010). The IPCC (2007) recognizes indigenous knowledge as an invaluable basis for developing adaptation and natural resource strategies in response to environmental problems. IPCC (2007) ur ges that

\section{掼 TU-CDES}


indigenous knowledge may prove useful while developing certain adaptation strategies that are cost-effective, participator y and sustainable. Research and practice on application of indigenous knowledge in climate adaptation is growing as an emerging idea in research and practice (MoSTE, 2015).

\section{Practical evidences}

The adaptation practices led by traditional institutions found effective and successful in many countries. Gender sensitive hurricane shelters have enhanced adaptive capacity of vulnerable women in Bangladesh. The traditional water governance system in Pakistan was successful that government later recognized this approach and replicated in other parts of the country. In China, community based institutions are responsible to set $r$ ules for prioritization and allocation of water since long past (Pradhan et al., 2012). Similarly, local people, through the use of indigenous knowledge systems, have able to reduce climate vulnerability in Sahel region of Africa (Nyong, Adesina \& Osman, 2007). Eger u (2012) presented that people of Teso su-region of Uganda use indigenous knowledge to detect drought and adapt to climate change. The author urges for documentation of such knowledge system to support global community to withstand against climate impacts. However, Nyong, Adesina and Osman (2007) are worried that indigenous knowledge is not widely taken into consideration in the design and implementation of planned adaptation strategies.

\section{Conceptual framework}

The conceptual framework for this research is framed as climate change and it's impacts are perceived not only by local people, these are also supported by the scientific data. The local community and the scientific community are responding climate change in own way, i.e. autonomous adaptation and planned adaptation respectively. However, this paper considers that indigenous knowledge combined with scientific knowledge can provide better adaptation opportunities to the local people. The acknowledgement of traditional institution can ensure good govemance management and sharing of natural resources with respect to climate adaptation. The Figure 1 presents the conceptual framework in diagrammatic form.

\section{Materials and Methods}

Mustang district (Fig. 2) was selected purposively as study site for this research. This district represents a unique Tibetan culture along with rich indigenous knowledge and strong traditional institution. The history of Mukhiyainstitution dates back to time immemorial and this stood independently during Shah, $\mathrm{R}$ ana, Panchayat, Multiparty system and the present Republican regime (Thakali, 2012). Thakali and Gur ung are two dominant ethnic groups who are adapting in this rain-shadow T rans-Himalayan landscape for centuries. On the other hand, Mustang district has prepared LAPA in the initiation of formal institutions.

Case-Study Research Design is followed as an approach to research (Yin, 2003). Researcher did in-depth study in Muktinath VDC. The primary data were collected using tools such as k ey informants interview (KII), focus group discussion (FGD) and field observation. Five FGDs were carried out with mother's group, entrepreneurs' group and local people. Similarly, KII was done with the members of women led co-operative, conservation management committee members, entrepreneurs, village $\mathbf{M u k h i a}$ (present and past) at the field level. Likewise, KII was carried out with relevant government institutions- District Soil Conservation Office, District Agriculture Development Office, District Development Committee, V illage Development Committees. Similarly, non-government officials for KII were from Annapur na Conservation Area Project, Human Development and Environment Concern Society, NGO Federation. The secondary data were collected from for mal institutions and reviewed their relevancy against research questions.

\section{Data Analysis}

The finding of the research is broadly divided into three subsections according to the research questions. The first sub-section reviews the climate change impacts in Mustang in general and Muktinath VDC, in particular. The second sub-section briefly discusses climate change adaptation in Mustang district. This includes planned adaptation and autonomous adaptation practiced

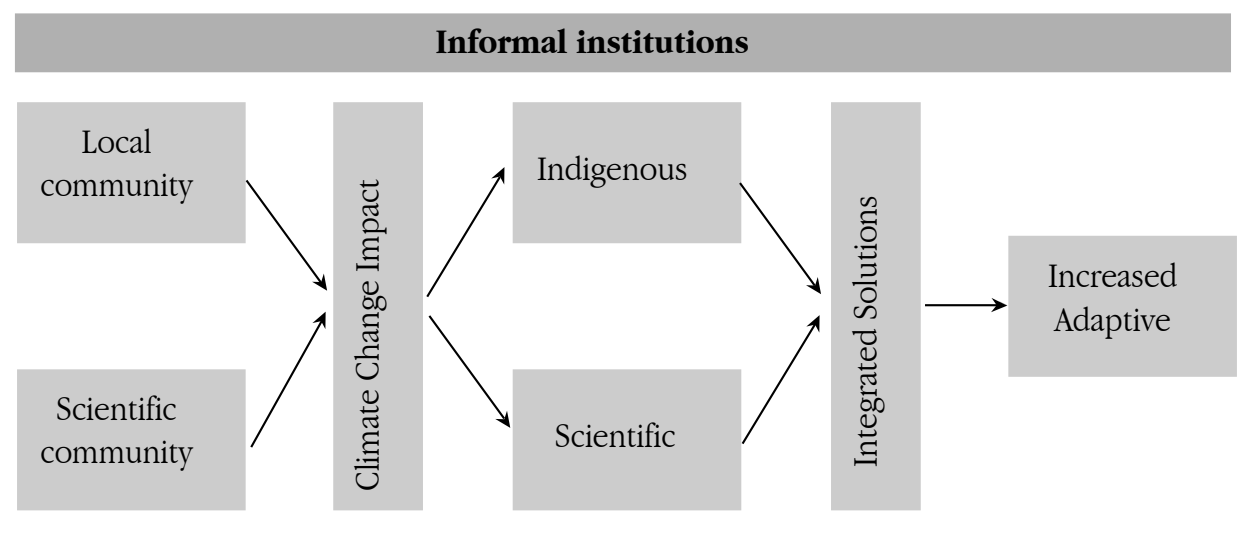

Formal institutions

Figure 1 Conceptual framework of the study (modified Mercer et al., 2010) 


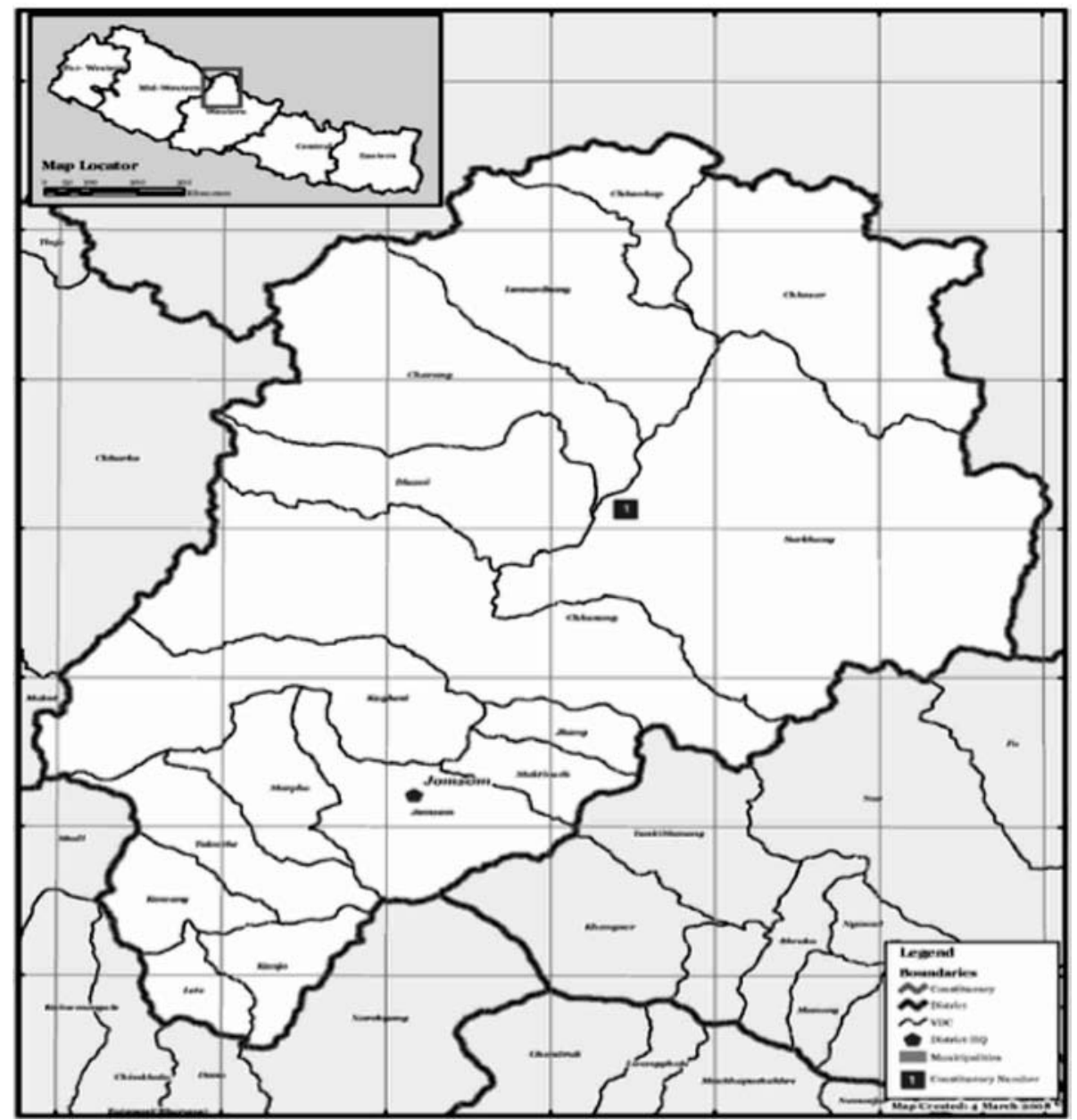

Figure 2 Location of Study Area

in Mustang district. The final section discusses the role of traditional institution with respect to climate adaptation. The findings are then discussed in consideration of national and intemational policy and practices.

\section{Result and Discussion}

Change in climatic pattern and impacts perceived

The climatic patter $n$ has changed in recent years in Mustang district. The meteorological data obtained from Jomsom station of Mustang for past 30 years (1981 to 2011) revealed that the temperature, rainfall and wind-blow are rising. The average minimum temperature in December (1981) was recorded as $2.76^{\circ} \mathrm{C}$. The average minimum temperature recorded in December (2011) shows an increase to - 1.3 (F ig. 3). Similarly, maximum average temperature in July (1981) was recorded as $12.72^{\circ} \mathrm{C}$. This average maximum temperature recorded in July (2011) shows $13.86^{\circ} \mathrm{C}$ (Fig. 4). Likewise, rainfall pattern (Fig. 5) has changed from the form of snowfall to the for $\mathrm{m}$ of rain and hailstor $\mathrm{m}$. In 1981, rainfall recorded in Jomsom was $250 \mathrm{~mm}$ while in 2011; it was recorded as $286 \mathrm{~mm}$. The average rainfall of last 30 years is $267.8 \mathrm{~mm}$. Similarly, wind blow from south to north reached to

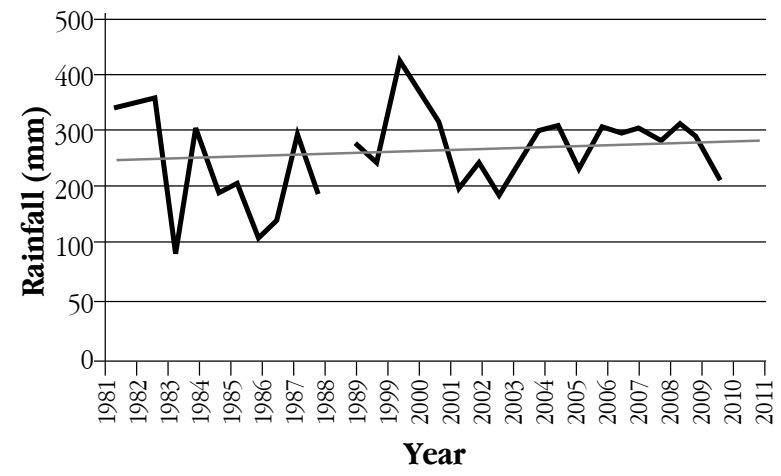

Figure 3 Annual Rainfall (mm) data for Jomsom

an average speed of 90 Naught from 50 Naught. Further, hailstorm started to fall in the lower region (DHM, 2012 as cited Muktinath VDC, 2016). Previously, the summer rain used to be only occasional and sporadic; however since few years back, it has become regular phenomena.

\section{A TU-CDES}


These changes in climate parameters resulted negative impacts. New diseases and pests appeared in agri-crops including high valued apple. There is reduction in production of non-timber forest products including Yarsha Gumba (Cordyceps sinensis). Increase is invasive species, drying of water sources, early ripening of crops, new types of diseases are noted for humans and livestock. Intense rainfall has affected traditionally built flat roofed houses made of mud and stone with roof leakage and wall erosion problems. The incidences of landslides, flood and inundation in farm land nearby Kaligandaki River have been increased (Muktinath VDC, 2016).

Increase in average annual temperature even raises the threats of glacier lake outburst flood (GLOF) in the region. These climatic consequences possibly put local inhabitants at high risk. $\mathrm{F}$ or example, an extreme snowfall in October (2014) resulted human casualty including international tourists. There was heavy snowfall in mid-day and rainfall at night which is, in the word of local cooperative chair of Muktinath, was unnatural.

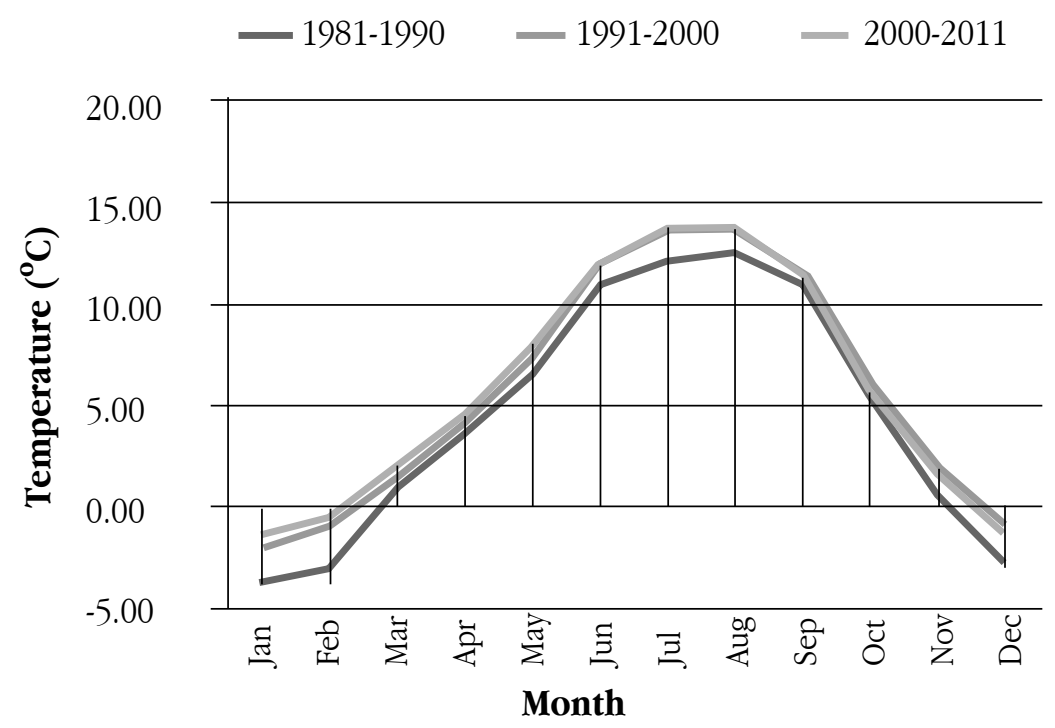

Figure 4 Minimum temperature data for Jomsom

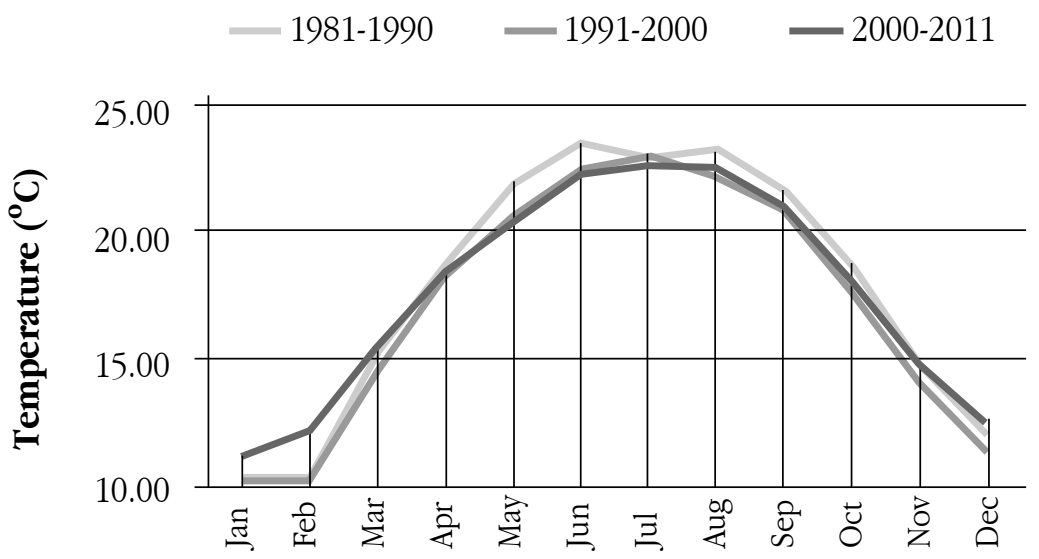

\section{Month}

Figure 5 Maximum temperature data for Jomsom 


\section{Climate adaptation in Mustang}

The climate change adaptation initiatives tak en in Mustang is presented in two ways. The first section presents planned adaptation led and facilitated by formal institutions, whereas the second section presents indigenous way of adaptation, autonomous adaptation, which is gover ned by the infor mal institutions. Planned and autonomous adaptation measures have been analysed taking a reference of Muktinath VDC.

\section{Initiation of planned adaptation}

Mukthnath VDC has prepared LAPA to combat negative impacts and har ness the positive impacts of climate change. Planned adaptation process was inclusion. During L APA preparation and implementation of some priority activities-Mukbiya and mother's group members were involved. L APA was prepared following a rigorous process of LAPA framework (MoSTE, 2011). The LAPA has identified a list of priority activities to be carried out immediately such as- plantation, riverbank control, protection of water sources, construction of drinking water ponds for cattle herds and promotion for alternative livelihoods. LAPA implementation action plan has also identified the potential or ganizations to provide budgetary and financial support. But this does not discuss the local adaptation measures use indigenous technology and cost-effective means of adaptation. The LAPAs are owned by formal institutions and accepted by local people.

\section{Use of indigenous knowledge in climate adaptation livelihoods diversification}

Local people of Mustang and Muktinath have already initiated autonomous adaptation through switching their traditional occupation and subsistence form of livelihoods. The warmer and shorter winter has increased the flow of tourists that led to open new and more comfortable hotels. People who used to grow cereal crops has started to establish apple orchards, commercial cultivation of vegetables and plantation of forest crops- Bhote peepal (Populus ciliate), Dhupi Salla (Cupresus species), Bains (Salix species) and Sea-buck Thorn (Hippophae tibetana) for commercial purposes.

This diversification of livelihood approach has provided income and employment at local level. This has supported by better access to market due to transportation facilities. People are making good income from agro-forestry products now, which were far less before. For example; price of apple increased from NRs 5 per kg to NRs 70; price of walnut reached to NRs 600 per $\mathrm{kg}$, and price of medium size mountain-goat to NRs 17,000 at village. The price of Bhotepeepal timber reached to NRs. 2200 per piece, depending on size.

Better access to market raised hope to local people. Chair person of local youth club shared that he sold timber worth one million and earned 0.6 million Nepalese rupees as net profit in the previous year. He proudly said that he was returnee from Japan who could not stay there even a year. Similarly, another Japan returnee, and now, chairperson of local co-operative, told that she invested NRs 1.5 million to enter into Japan. But, she retur ned within three months and started hotel business. She is now making good income from her hotel business and actively involved in cooperative and in sea-buck thorn enterprise.

\section{Case I: Indigenous knowledge for successful plantation in Jharkot}

For people of Jhark ot, firewood was only ener gy source for cooking and heating. They used to spend days and nights to collect firewood from a distant natural forest. Village rule permits them to collect limited amount of firewood- five bhari (head load) per member for each household. In late 1980s, govemment launched afforestation scheme and encouraged local people for plantation. Both the government and local people involved in plantation movement. In 1989, local people first planted 400 stumps of Bhote-peepal and they continued the plantation adding Dhupi Salla (Cupresus species) and Bains (Salix species) in the following years. The number of plantation exceeded over 25,000 stumps and reported to be successful in Jharkot village.

However, the plantation done from the gover nment initiative failed. It was explored that the government adopted a technical approach of plantation- mathematical calculation of number of seedlings per hectare. They missed to calculate soil and climatic condition of Mustang and hurried for plantation of seedlings not stumps. Further, government officials followed tender approach for plantation which failed to ensure post-plantation care- watering, weeding and protection from high blowing wind. In addition, without participation and consultation with local people, large number of seedlings were planted which was, in the view of local people, unmanageable. Local people argued that government officials were overlook ed technical dimension for plantation suitable of that location. So, they could not manage watering for seedlings. In their experience, each seedling needs about 5 litre water per day in dry summer season.

Regarding their knowledge on plantation, one participant shared, "We start cutting of Bhote peepal stumps on $4^{\text {th }}$ week of Baishakh (second week of May) on Thursday each year. We believe any stumps planted on Thursday confim survives". Another participant said, "According to our cultural belief person belonging to Fire Zodiac Sign are not allowed to cut stump and or harvest. If it is done, plant dies. He further added that he belongs to Fre Zodiac Sign and claimed that this is proved from his experience.

Local people planted more than two stumps per pit. They gave the logic that two stumps planted together support each-other to withstand against high blowing wind. This also provides stumps capacity to tolerate cold temperature. They knew that 
two stumps can merge into single one, while growing or if one dies the probability of survival of next is high.

The government officials at District Soil Conser vation Office, Mustang agreed that plantation of two or more stumps per pit also prevent stumps from being shak en. If stumps shake, they could not root. He further told that people were aware of cracks or damage at the cutting ends of stumps and they avoid such stumps during plantation. The size of stumps (2.0-2.5 metre long and $10-15 \mathrm{~cm}$ girth) is also technically appropriate. He further shared that gover nment later adopted the same approach of plantation in Jharkot and replicated in other parts of the district which success rate was high.

\section{Case II: Sea-buck thorn enterprise: local governance external technology}

Before 1999, fruit of Sea-buck thorn used to use for treatment of joint ache and to add sour taste in food items. In 1999, govenment institution, Tree Improvement and Stand Component (TISC) made local people aware about its commercial value through making squash. Later, other formal institutions provided support to local people with advance technology and marketing of the products. During discussion, entrepreneurs group shared that they produced more than 7000 litre squash and ear ned more than NRs 2.240 million in a single year. This enterprise $r$ uns under mother's cooperative group. This group set $r$ ules on conser vation, processing, benefit sharing. Mother group set days for fr uit collection and local people collect fruits without making any harm to plant. Mothers' group has set penalty equivalent $r$ upees NRs 500 for damaging plants. The mother's group buys fresh seeds of Sea-buck thorn and process it in well-equipped plant. The labelled squash is marketed locally as well as at national market. By-product of Sea-buck thorn is sold to local middlemen, which he trades to international market to make anti-ageing creams. So, local people are aggressively planting Sea-buck thor $\mathrm{n}$ in far mlands and communal lands. Local people have realized that without awareness, technical and financial support from formal institutions, they could not have made such income.

Local people have adapted the processes of implementation activities supported by for mal institutions. Though, they work collectively and share benefit equally, they prepare official documents as per the requirement of formal institution. This does not mean that they have misused financial resources or compromised the quality of deliver $y$. This is the acceptance of government rule without violating village rule. One participant shared that, "... We acknowledge r ules of for mal organization because we need development support and we also cannot go against village rule."

\section{Role of Mukbiya institution}

Mukhiya in general, provides leadership of local communities and execute village rules. As per village norms/rule, formal institutions should take consent from Mukhiya before implementation of development programme. Mukbiya gives consent on the ground that the interventions shall benefit to the community at lar ge. $\mathrm{S} /$ he shall even reject development programmes, if $\mathrm{s} / \mathrm{he}$ beliefs that development programme shall not do good for the community. Local people have strong trust on Mukbiya institution and feel pride of that. With respect to research subject, role of Mukbiya is decisive in the forest plantation, forest products sharing and operation of sea-buck thor $n$ enterprise. Mukbiya ensures equality in participation as well as in benefit sharing. The Mukbiya ensures protection of plantation site. In retur $\mathrm{n}$, each member household gets 3 bhari (head load; 1 bhari $=$ about 30 $\mathrm{kg}$ ) of firewood from community plantation and 5 bhari of firewood from natural forest. Mukbiya has authority to fix the rate for forest products surplus to sale outside the community.

Though Mukbiya apparently looks as an autocratic institution, in reality they are elected democratically by the village assembly for the period of two years. The practice shows that there is less chance of repetition of same Mukhiya for second term. Village assembly can reward/punish him/her based on their performance during their tenure. However, formal institutions are bounded to execute government rules which sometimes mismatch with local village rules. For a government official, taking consent from village Mukbiya prior to implement gover nment approved development programme is considered humiliating. They are in difficult position as they could neither enforce government rule nor formally recognize and practice all the rules of local institutions as in some cases they contradict to each other. But, there is no way other than to accept and move forward. On the other hand, local people could not give up their practice. So, the middle way adopted was to implement climate change adaptation programmes as per their rule, but sharing of benefit as per the local village rule. Moreover, both institutions have realized mutual respect and recognition of each-other and need of combined use of knowledge for better adaptation to climate change.

The change in climatic patterns: temperature, rainfall and wind is perceived by the local people which are verified by the scientific evidences. The changes in climatic patter $n$ have posed both positive and negative impacts. L ocal people have practiced autonomous form of adaptation- through livelihood diversification, whereas for mal institutions have initiated planned adaption measures. Improved access to mark et has made livelihood diversification process easier. But, in planned adaptation plan, there is clear gap in recognition and use of indigenous knowledge and mobilization of Mukhiya institution in the adaptation process. But, in practice, traditional institutions and formal institutions, both are complementing for climate adaptation. L ocal people are receiving scientific knowledge from formal institutions and formal institutions have learned from indigenous practices. Forest plantation in Jhark ot presents success case of indigenous knowledge system. 
Whereas, the Sea-buck thor $n$ enterprise proved that scientific technology works better than indigenous technology for commercialization and thereby making good income and creating employment opportunities.

Stronger informal institutions have suppressed formal institutions in Mustang. There is invisible conflict between formal and informal institutions regarding gover nance of natural resources and implementation of development programmes including climate adaptation. Strong community ownership and cohesiveness combined with rich knowledge of natural resource management has forced for mal institution to accept infor mal institutions.

\section{Climate Scenario}

The research on climate projections clearly revealed that there is substantial increase in war ming in Himalayan region. This is approximately 3 times the global average. IPCC (2007) has projected that average annual mean temperature can rise about 3 degree Celsius by 2050 s and about $5^{\circ} \mathrm{C}$ by 2080 s. Similarly average increase in rainfall in Tibetan plateau is projected to $10-30 \%$ by 2080 s. The rise in $2-3^{\circ} \mathrm{C}$ is considered potentially catastrophic for Himalayan people and ecosystems (Xu et al., 2009). The lik ely negative impacts from this includes rapid reduction of glaciers effects on river flows, ground water recharge, natural hazards; biodiversity, ecosystem composition, str ucture, and function; and human livelihoods (Xu et al., 2009; ICIMOD, 2009). Climate adaptation is of urgent need of people living in mountain and downstream (ICIMOD, 2009).

In this context, adaptation rather than mitigation is upfront need of mountain people. Agrawal, Kononen and P errin (2009) also insist for livelihood diversification as strategies for adaptation for these people. They argue that diversification reduces risks across assets owned by households or collectives. Similarly, communal pooling involves joint ownership of assets and resources; sharing of wealth, labour or incomes from particular activities across households, or mobilization and use of resources held collectively during the period of scarcity (Agrawal, Kononen \& Perrin, 2009). In climate adaptation intervention, Nakashima et al. (2012) and MoSTE (2015) argued that locally evolved knowledge, technology and practices provide better options than formal responses. Other scholars (Naess, 2013; L abel, 2012, Chaudhur y, 2012 as cited MoSTE, 2015) have also suggested not relying solely on scientific knowledge and tools. They have argued that scientific knowledge and tools can be unavailable or costly to practice in most cases in rural areas.

Though Regmi and Bhandari (2013), highlighted the role of fomal institutions that they can play an important role to shape access to and control over resources for the benefit of more vulnerable people. In the context where informal institutions are capable in doing so, Fuys and Mwangi et al., 2006 as cited in Kotr u et al. (n.d.) asserts that informal institutions do well. Because they are well aware on local environmental challenges and function as per customary law and practice, group tenure and collective efforts on resource management.

Thakali (2012) argued that informal governance structure plays important role in collective management of natural resources. He further stresses that forest, water and pasturelands were not treated as open access even when central govermment had limited jurisdiction in Mustang. Pradhan et al. (2012) highlighted on flexibility of traditional institutions. They assert that such institution can work in the inter face of village r ule and government rule. Though Kotru et al. (n.d.) war ned that traditional for $\mathrm{m}$ of governance is caught between modernism and traditionalism; the evidences of Mustang do not show that.

In the dilemma of for mal and traditional institutions, Agrawal (2008) suggests for mutual recognition of role of both the forms of institutions. He believes that mutual recognition can lead adaptation inter ventions and investments successfully and sustainably. Nyong, Adesina and Osman (2007) urged to integrate indigenous knowledge in for mal climate adaptation processes. They argued that this knowledge helps in decision making system which is based on observed indicators or relationship with events. This also provides space for participation for indigenous people, who practice collective resource generation, equity in benefit sharing and aware on environment protection. These are in-line with common principles of sustainable development framework.

Incorporation of indigenous knowledge into climate change policies adds value in climate adaptation strategies (Nyong, Adesina \& Osman 2007; MoSTE, 2015). Such practices can be observed in community based forestry and ir rigation system in Nepal. But, systematic guidelines on how to incorporate them into for mal process are not produced yet (MoSTE, 2015). Moreover, there are operational level obstacles in integration of indigenous knowledge to formal climate strategies. The first is related to recognition of need and the second is the process of integration, i.e. how to integrate (Nyong, Adesina \& Osman, 2007).

\section{Conclusion}

People of Mustang have witnessed climate change and its negative impacts since long and responded them through autonomous adaptation. The practice of indigenous knowledge in forest plantation and diversification of livelihood strategies presents good examples of autonomous adaptation. In the context of climate adaptation, the role of traditional institution, Mukbiya is critical to take decisions related to natural resource management, people participation and practice of equity in benefit sharing. On the other hand, planned adaptation to climate change has started with the facilitation of government led formal institutions. The role of formal institution was the assessment of future climate

\section{螣 TU-CDES}


risks and to provide technical know-how and support building adaptive capacity. Moreover, the recognition of the link that connects traditional institutions with formal institutions is missing. Likewise, formal institutions yet need to integrate indigenous knowledge in planned adaptation process. Thus, this paper urges for recognition of informal institution and integration of indigenous knowledge in planned adaptation process which brings synergy in adaptive capacity building of local people. This paper further argues for the documentation of indigenous knowledge for current and future use in climate change adaptation.

\section{References}

Agrawal, A. (2008). The Role of Local Institutions in Adaptation to Climate Change. Washington DC: Social Development Department, the world Bank

Agrawal, A., Kononen, M. and Perrin, N. (2009). The Role of Local Institutions in Adaptation to Climate Change. Social Development Working Papers: World Bank. No. 118

Ajani, E.N., Mgbenka, R.N. \& Okeke, M.N. (2013). Use of Indigenous Knowledge as a Strategy for Climate Change Adaptation among Farmers in sub-Saharan Africa: Implications for Policy. Asian Journal of Agriculture Extension, Economics and Sociology. Vol. 2 No. 1 pp. 23-40

CBS (2011). National Population and Housing Census. Kathmandu: Government of Nepal, National Planning Commission Secretariat, Central Bureau of Statistics

Chaudhary, R.P., Bhattarai, S.H., Basnet, G., Bhatta, K.P., Uprety, Y., Bhatta, L.D., Kotru, R., Oli, B.N., Sharma, L.N., Khanal, S., Sharma, U.R., (2017) Traditional practice and knowledge of indigenous and local communities in Kailash Sacred Landscape, Nepal. ICIMOD Working Paper 2017/1. Kathmandu: ICIMOD

Dahal, N. (2005). Perceptions of Climate Change in the Himalayas. Tiempo Climate Newswatch. Accessed date: 10/15/2014 retrieved from

DDC Mustang (2013). District Profle of Mustang District. Mustang: District Developent Committee, Government of Nepal

DDC Mustang (2016). Minute of District Council. Mustang: District Development Committee Mustang. Government of Nepal

DHM (2012). Meteorological Data for Jomsom Station, Mustang. Kathmandu: Department of Hydrology and Meteorology, Government of Nepal

Egeru, A. (2012). Role of Indigenous Knowledge in Climate Change Adaptation: A Case Study of Teso sub-region Eastern Uganda. Indian Journal of Traditional Knowledge. Vol. 11 No. 2 pp. 217224

Forsyth, T. and Evans, N. (2013). What is Autonomous Adaptation? Resource Scarcity and Smallholder Agency in Thailand. World Development. Vol. 43. pp. 56-66

Fussel, H.M. (2007). Adaptation Planning for Climate Change: Concepts, Assessment Approaches and Key Lessons. Integrated Research System for Sustainability Science and Springer
GoN (2011). Climate change Policy of Nepal. Kathmandu: National Planning Commission, Government of Nepal

ICIMOD (2009). Climate Change in the Himalayas: Information Sheet \#3. Kathmandu: International Centre for Integrated Mountain Development

IFAD (2009). IFAD's Response to Climate Change through Support to Adaptation and Related Actions: Comprehensive Report. International Fund for Agriculture and Development

IPCC (2007). Climate Change 2007: The Physical Science Basis, Contribution of Working Group I to the Fourth Assessment Report of the Intergovernmental Panel on Climate Change. United Kingdom and USA: Cambridge

Kotru, R., Pradhan, N. and Jodha, N. (n.d.). From Customary to Customized Institutions for Adaptation to Change in the Mountains. ICIMOD: Kathmandu

Mercer, J., Kelman, I., Taranis, L. and Suchet-Pearson, s. (2010). Framework for Integrating Indigenous and Scientific Knowledge for Disaster Risk Reduction. UK: Overseas Development Institute. pp. $214-239$.

MoSTE (2010). National Adaptation Programme of Action to Climate Change. Kathmandu: Ministry of Environment Science and Technology, Government of Nepal

MoSTE (2011). National Framework on Local Adaptation Plan of Action. Kathmandu: Ministry of Environment Science and Technology, Government of Nepal

MoSTE (2015). Indigenous and Local Knowledge and Practices for Climate Resilience in Nepal: Mainstreaming Climate Change Risk Management in Development. Kathmandu: Ministry of Science Technology and Environment, Government of Nepal

Muktinath VDC (2016). Local Adaptation Framework of Action for Muktinath VDC. Muktinath Village Development Committee: Mustang

Naess L. O. (2013). The role of Local Knowledge in Adaptation to Climate Change. Wiley Interdisciplinary Reviews: Climate Change. Vol. 4 pp. $99-106$

Nakashima, D. Galloway, J., McLean, K., Thulstrup, H. D., Ramos Castillo, A. and Rubis, J.T. (2012). Weathering Uncertainty: Traditional Knowledge for Climate Change Assessment and Adaptation, 120. Paris: UNESCO, and Darvin, UNU

Nyong, A., Adesina, E.F.Osman E.B. (2007). The Value of Indigenous Knowledge in Climate Change Mitigation and Adaptation Strategies in the African Sahel. Springer

Pradhan, N. S., Khadi, V.R., Schipper, L., Kaur, N. and Geoghegan, T. (Eds.) (2012). Role of Policy and Institutions in Local Adaptation to Climate Change. ICIMOD: Kathmandu

Regmi, B.R. and Bhandari, D. (2013). Climate Change Adaptation in Nepal: Exploring Ways to Overcome the Barriers. Journal of Forest and Livelihood. Forest Action: Kathmandu. Vol (11) No. 1 pp 43-61

Rimal, G. N. (2011). Infused Ethnicities: Nepal's Interlaced and Indivisible Social Mosaic (Enlarged 3rd Edition). Kathmandu: Institute for Social and Environmental transition Nepal 
Sherpa, P.D., Sherpa, G., Ghale, K., Lama, K., \& Sherpa, P. (2013). Revitalizing Customary Governance and Strengthening Traditional Knowledge on Natural Resource Management in Nepal. In Indigenous Peoples, Forests and REDD Plus: Sustaining and Enhancing Forests through Traditional Resource Management. Philippines: Tebtebba Foundation. pp 195-266

Thakali, S.B. (2012). Localising Environment: Mustang's Struggle to Sustain Village Autonomy in Environmental Governance. PhD Thesis Submitted to Lincoln University New Zealand.
Xu, J., Grumbine, R. E., Shrestha, A., Eriksson, M., Yang, X., Wang, Y. and Wilkes, A. (2009). The Melting Himalayas: Cascading Effects of Climate Change on Water, Biodiversity, and Livelihoods. Conservation Biology. Vol. 23. pp. 520-530

Yin, R. K. (2003). Case Study Research: Design and Methods, 3rd Edition. Thousand Oaks, CA: Sage Publication. 